\title{
Real Option As The Tool For Valuation And Strategic Guidance For The Post-Industrial Organizations
}

Deepak Kumar Subedi, (Email: deepak@Marshall.edu), Marshall University

\begin{abstract}
Post industrial organization puts premium on flexibility, and also on assets that confer flexibility. In the post-industrial business environment, uncertainty need to be understood and managed to reap the potential benefit. Flexibility in organization enables it to take benefit of such uncertainty. Flexibility can be increased by tangible assets; and also by intangible assets like knowledge, group work, routine and experience. "Real options" confer value to flexibility. Besides valuation It also provides decision making guidance for managers involved in identification, acquisition and development of (both tangible and intangible) resources that post industrial organization require to make itself flexible.
\end{abstract}

\section{INTRODUCTION}

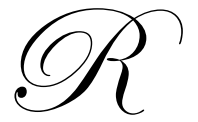

ecently interests in the "real option" have increased (Ander and Levinthal, 2004; Ander and Levinthal, 2004b; Copeland and Tufano, 2004; McGraith, Ferrier and Mendelow, 2004; Leiblein; 2003; Zardkoohi, 2004, Amram and Kulatilaka, 1998). Real option provides economic rationale and basis for valuation for strategic and operational flexibility stemming from resources such as knowledge (implicit as well as explicit), network of relationships, work teams, routines, flexibility and experience etc. (McGrath et al., 2004; Leiblein, 2003; Pandze, Horsburg, Gorton and Polajnar, 2003) Acquisition and utilization of such resources play prominent role in the in the "post-industrial organizations (Doll and Vondermbse, 1991). "A bulk of the value of postindustrial organizations (virtual organization) is represented by the "real option" (Venkatraman and Henderson, 1998).

On the other hand, evaporation of values of many e-commerce businesses has raised doubts on the wisdom of those high values in the first place. High values of some organizations were the outcomes of deceptive figures. Examples are companies like Enron and World com. But crash was wide spread, suggesting that whole market was overvalued in the first place. After the crash, the values of e-commerce stocks are found to be closer to the present value calculated with the traditional discounted cash flow method (Koller, 2001). That prompted some experts to suggest that the "real option" only provided seemingly economic justification to the behavioral outbursts (Ander and Levinthal, 2004).

In the midst of these disagreements one may ask how real the real option is. Disregarding real option makes valuation to be solely based on the discounted cash flows. This method is adequate for tangible asset based industrialera organizations, but fails to take notice of resources like knowledge, network of relationships, work teams, routines flexibility and experience etc. mentioned above. Therefore, the discussion on real option has implication on whether or not we believe that economy has moved from industrial (which is essentially tangible asset based) to the postindustrial (knowledge based) (Huber, 1984; Doll and Vondermbse, 1991). Ignoring the real option reduces the value of innovation and flexibility dramatically, and makes investments in many of such projects unfeasible. Besides, it also makes strategy of identifying, acquiring, developing and deploying such assets impractical (Kogut and Kulatilaka, 2004; Liebel, 2004).

Discussions in rest of the paper are organized as following. First, we discuss options. Since real options have its root on financial options, they need to be explained before explaining real options. After that we discuss the post- 
industrial organization, see how real option can explain a bulk of the value of such organizations. Then we show how assumptions and implications of real options (when compared to those of traditional discounted cash flow calculation) suits better for post industrial organization.

\section{FINANCIAL OPTIONS}

Real options have their roots in the financial options. Basically there are two types of (financial) options; which are call option and the put option. The discussions of options here are drawn from finance text books including Copeland and Weston (1992) and Hull (1997).

Call option allows the option holder (buyer of call option) to buy the underlying asset (which can be stocks) at a predetermined exercise price. The option holder exercises the option if the asset's price is higher than the strike price. The exercise gives the option holder a profit, equal to the difference between the current price of underlying asset and the strike price. If the price of the asset (stock) goes down, the option holder is under no obligation to buy, and the option expires without exercise. The maximum potential loss is the total amount that option holder paid to buy it in the first place.

Higher the uncertainly in the environment, and longer the time left before the option expires, more valuable the option becomes. Higher uncertainty means the asset value can have bigger swings. If the value goes down, the option holder is under no obligation to buy. Loss for the option holder in any case is the price she paid for the option. But higher up the price of the asset goes, bigger the margin of profit can be for the option holder. Similarly, longer time to expiration allows more opportunity for option holders to see in which direction the price of underlying asset moves. Of course, option holder can always exercise if the price is favorable. This asymmetry favoring the option holder makes it a desirable investment (Copeland and Tufano, 2004 and McGrath et al., 2004).

Put option on the other hand allows the option holder to sell the underlying asset at the predetermined strike price. This option is bought to place a floor on the amount of loss. If the price of asset is above the strike price, the option expires unutilized. However if the price happen to go down the option holder can sell it at the predetermined price. Mutual fund managers can use the put option as an insurance against the possible loss in the value of the assets they manage. The value of this option is also affected by "uncertainty" and the "time to expiration. "

\section{REAL OPTIONS}

In real options the underlying assets of concern are real assets such as oil, drugs, new products, new ventures and any such assets. These assets are different from the financial assets (such as stocks or bonds), which are the underlying assets in financial options (Copeland and Tufano, 2004; Copeland and Philip, 1998; Copeland and Philip, 1998b; Copeland and Weston, 1992; Luherman, 1998, Amram and Kulatilaka, 1998). Again, whereas the financial options are explicit and entails formal contract, the real options come without label. It is managers' job to formulate, understand, identify and manage the options.

Two important types of real options "growth option" and "option to abandon," are closely related to the call option and the put option of the financial counterpart (Pandza et al., 2003; Kogut and Kulatilaka, 2004).

Few of the important growth options are explained here with examples. Suppose that, there is a plot of land with oil (petroleum) mine underneath it. And, further suppose that experts believe that drawing oil would be viable only if its price is above sixty dollars per barrel. Investing in this plot of land is then like buying the call option. If the oil price goes above sixty dollars, further investment can be made to extract the oil. The amount for this investment is analogues to strike price. Buying this land provides possibility of growth to the organization, but puts no obligation to extract oil until the time is right. This is a classic example of the growth option (Lislie and Michaels, 1997; Copeland and Keenan, 1998).

Another example is the investment in research and development ( $R$ and D.) A drug company engaging in " $R$ and D" treats its investment as acquisition of option. If the research reaches to a positive conclusion, further 
investment can be made to produce the drug in the large-scale (like exercising the option.) Otherwise, the investment in that particular research should be written off (loss of the price of the option) (Lislie and Michaels, 1997; Copeland and Keenan, 1998).

We may also consider that $\mathrm{R}$ and $\mathrm{D}$, progresses through different stages. Suppose, the success of one particular stage determines whether or not human testing of the drug is carried out. Success in this stage leads to the exercising of the first option, the outcome of which is the acquisition of another option (human testing.) Many R and D projects are conceptualized as series of nested options (options on options.) Not just Rand D, most innovations in organization goes through the series of stage-gates. At each of the gates, decisions, on whether to go to the next stage (exercise the option) or kill the project (not exercise it), are made (Kogut and Kulatilaka, 2004; Hamilton and Mitchell, 1990; Copeland and Keenan, 1998).

Many venture capitalists view their investments as real options. At each stage they decide whether or not to move to the next stage. If they go through all the stages, they can reap the benefit, by selling their asset in the primary stock market (Kogut and Kulatilaka, 2004).

Option to abandon is like put option. Investing in generic production facility instead of specialized facility (for example) allows investors to sell the facility, and get out of their investments easily (if they so desire.) Specialized production facility can be of no alternative use and can have very low value for other investors (Copeland and Weston, 1992). This is an example of option to abandon. This is like buying insurance for the investment. Investments with put option have higher value.

One classic example of put option, is British governments offer to buy back the share of BP, at a predetermined price if its market value goes below certain level. It is like selling the option to abandon (put option) to the share buying public by the government. The shares were being sold as a part of its privatization plan. Experts believe that the offer not only boosted the faltering privatization effort, but also caused the price to rise to incorporate the value of put option in it (Riddell, 1987; Jonguieres, 1987; Wilkinson, 1987) .

The option to abandon has recently gained attentions of researchers. This may point to the need of adjusting organizations' decision making process. Organizations are biased towards status quo and are reluctant to alter the course, making the option to abandon unrealizable even if they are theoretically present. Aside from that, people object to the idea of killing projects. Once killed, it will have no economic value. Positive information that may come in future will be of no value as well (Ander and Levinthal, 2004). However, the option to abandon need not be taken literally; ability to put assets to alternative use can be considered as the part of this option (Kogut and Kulatilaka, 2004).

Another option that is gained considerable attention is "option to wait." With the uncertainty in technology and potentially huge investment, the option to wait and gather more information before making full investment is highly valued. The real options that researchers have identified include "the option to defer, the option to stage and sequence investment, the option to alter operating scale, the option to abandon, the option to switch inputs or outputs, growth options and multiple interacting options" (Trigeorgis, 1993).

Options are conferred to organizations because of their flexibility. Options that come out of flexibility can be growth or options to abandon or both. Flexibility stem from bundle of resources and capabilities. Resources and capabilities are unique to each organization. As a result each organization's options are unique.

Gerwin (1993) suggested flexible production system generates option for organizations. Others have used option approach to value the flexibility conferred by advanced manufacturing system (Kumar, 1995, Ramasesh and Jayakumar, 1993). Focusing on especial kind of flexibility, Kulatilaka (1993) analyzed the option value of a duel fuel industrial steam boiler. One or the other of the fuels (which ever is cheap) at the moment can be used to run the boiler. Generic production facility, which can be used to produce different goods as the situation arises, can also confer option. The possibility of alternative use puts a floor to the loss in the value of investment (Kogut and Kulatilaka, 2004). Similarly, the ability to design and produce modular parts creates opportunity to provide great number in 
outputs without increasing the variety in production. This can be a growth opportunity (Baldwin and Clark, 1997). Similarly, the information systems also increase the flexibility and bestow the real options (Kumar, 1999).

\section{REAL-OPTION FOR VALUATION OF POST-INDUSTRIAL ORGANIZATIONS}

Avoiding "uncertainty" was the mantra of the industrial era business management practice. Then, only uniform outputs from mass production were available for the customers. Inventory was used as cushion to ward off small fluctuation in demand (Galbraith, 1978). With time, competition among producers increased forcing them to vie for customers' attention, which led them to add variety and sophistications in products. As a consequence customers started to become more demanding. And, at the same time newer technologies (advanced manufacturing, computer and communication, intranet and internet etc.) have exploded, adding capability of firms to compete (amongst themselves) and provide newer product and service (to their customers,) and also of customers to demand more personalized service and customized products (Doll and Vendormbse, 1991).

In order to survive and thrive in this changing environment, organizations have to be flexible and innovative. They should also be able to explore and experiment and collaborate as needs arise, and dissolve such relationships when situations changes (Upton and McAfee, 1996, Ching et al., 1996).

As can be understood from our discussions, the "real option" can value the potential benefits stemming flexibility, innovation, exploration and experimentation (Kogut and Kulatilaka, 2004). Therefore, it is only natural that a larger portion of market values of the vast majority of post industrial organization (many of them are so called dot com companies) can be explained by the amount of "real option" they posses (Venkatraman and Henderson, 1998).

However, questions are raised, especially after the massive loss in values of e-commerce stocks, as to the wisdom of adopting the real option approach. Some thought that real option acted as a theoretical cover for the irrational exuberance of the share buying public (Anderson and Levinthal, 2001). Others even showed that, after the stock market crash, the values of what remained of e-commerce stocks reflected the tradition discounted cash-flow (Koller, 2001).

To these critics, we have three suggestions. First, real option approach does not deny the appropriateness of calculation of values with discounted cash flows. It values uncertainty and time besides the cash flows. Uncertainty reflects the potential for upside gain. Time is the window available to decide whether or not to exercise option. Once uncertainty is resolved and time to make decision comes, the value of project is essentially the discounted cash flow. If the upside potential is confirmed the value of the project increases accordingly, otherwise it goes down (Luherman, 1998). It can be surmised that, when it was shown that value of e-commerce stocks were fully accounted for by the discounted cash flow method, uncertainty involved in many of these business were resolved. Uncertainties were resolved in many cases with conclusion that hoped boon from e-commerce failed to be realized.

Why then the potential for so many of new firms (which were started with big bangs) have to be revised downwards? For this we have second suggestion. We can ask what proportion of research and development projects of drug companies actually succeed? Or, what proportion of venture capital projects is successful? During the industrial era, the mainstream of industry was reflected by stable organization whose future was more or less certain. And, the projects such as " $\mathrm{R}$ and $\mathrm{D}$ " represented only a small fraction in overall value. The post-industrial business however consists mainly of projects of the nature of "Rand D" or venture capitalists' undertaking; where potential for growth and uncertainty are both high (Huber, 1984). The uncertainty is reflected in customers demand, competitors' actions, new technology, organizational form and also in the market value of the organization.

Third, there is no denying to the possibility of existence of bubble in stock value. Time and again bubble has resurfaced. It could be the great tulip price bubble of the past, or the stock price bubble of nineteen eighties' Japan, the effects had been devastating and widespread. But, potential existence of bubble should not be an excuse to rebuff the insights provided by a well established theory. 


\section{IMPLICATIONS OF CHOOSING REAL OPTIONS AS STRATEGIC GUIDE}

Business practices and theories deal with management of "uncertainties" (Leiblein, 2003; MCGrath, 2004). The industrial era approach focused the downward risk of "uncertainty" and management practices and theories suggested ways to avoid it. Automation of production facility or the inventory management undertaken at that era reflected the predisposition towards uncertainty avoidance (Galbraith, 1974). On the other hand, uncertainty cannot be effectively avoided in the post-industrial era. The real option approach allows organizations to positively benefit from uncertainty, while limiting downside risks.

This difference in approach in dealing with uncertainty has impact on the kinds of investments organizations make, the way technologies are used, types of skills required, the way managers exercise their oversights and also how firms are organized within and in their relations with each other.

During industrial era, technologies were used to automate and impose uniformity and continuity so that human interventions are not required. The valuation method using discounted cash flow assumes no changes and no managerial intervention, after the decisions on investments are made. As uncertainties in business environment increased, the business reality has changed as well (Fine, 1998). When organizations were being computerized it was thought to be another step towards automation at the beginning. However, it was soon found that managers need to actively intervene. They need to utilize their conceptual and practical skills, imagination and creativity to reap maximum benefits from computerization (Zuboff, 1982). Importances of managers' theoretical and practical skills are critical for the success of newer technologies like advanced management technology (Boyer et al., 1997; Frohlich, 1994), and new management practices like quality management (Mukaherjee and Laperè, 1990) or business process engineering (Sucliffe, 1999). It is also found that activeness and effectiveness of play critical roles in determining the extent of profitability of the organizations, in the face of uncertain business environment (Swamidass, and Newell, 1987).

Acquisition and exercise of option requires managers' decision and intervention at every critical stage. In order to do that, managers need to understand the outside environment as well as the organizations' capabilities (Leiblein, 2003). Besides, it is suggested that for organizations to align their practice with the demands of real options, managers should increase their oversights and frequency of evaluations of projects (Kogut and Kulatilaka, 2004). Real options have to be framed, acquired, developed, managed and exercised by mangers using their judgments, conceptual and practical skills. Real options put more demand than even the financial options on managers (Leiblein, 2003; Pandza et al. 2003).

With increase in environmental uncertainty it is found that firms increase the utilization of information technology (Mendelson and Pillai, 1998; Mendelson and Pillai, 1999). This utilization enhances organizations' capability to get information as it happens, connect seamlessly with outside organizations as and when needed and, ultimately to serve customers with product and services customized to their tastes (Venkatraman, 1998). Utilization of information technology as such may not increase "efficiency" in traditional sense. Therefore the present value calculation using discounted cash flow cannot account for the all of the value that utilization of information technology bestows on the organization. The enhanced value that comes from utilization of information technology can be captured using real option approach (Kulatilaka and Venkatraman, 2001; Kumar, 1999).

Ability to design and produce modular parts also enhances the organizations capability to provide customized products. Modular parts are designed and produced individually, and yet they can function together seamlessly so the complex product as a whole functions well. Modularization of parts allows organizations' to combine their parts with those of others, and bring out the product quickly to capture the market demand as it surges. IBM's entry into the PC market in 1980's provides example of growth opportunity captured by flexibility stemmed from the modularization of the parts. This "growth option" is only captured if real option approach is used in valuation and decision making (Baldwin and Clark. 1997; Sako and Murray, 1999; Fine, 1998; Kogut and Kulatilaka, 2004).

And because modularized parts can be combined in different combinations, it makes easy for manufacturers to increase varieties and provide customized products without increasing the varieties in production so much. 
Flexibility provided by modularization of parts along with the digital connection are the main source of flexibility in organizations known as virtual organization, e-business or dell model in different context by different authors (Fine and Raff, 2000; Venkatraman, 1998; Kulatilaka and Venkatraman, 2001; Margretta,1998).

Similarly, post-industrial organizations value such intangible assets as team work, network relationships, trust and knowledge (explicit and tacit) (Doll and Vondermbse, 1991; Ching, Wholesapple and Whinston, 1996). All of them add flexibility, but their value is not generally captured by discounted cash-flow valuation only. Real option provides economic rationale and valuation of such intangible assets (Leiblein, 2003; Pandza et al. 2003). Aside from that, post-industrial organizations need formal and rational decision making process, which can utilize the knowledge and skills embedded in organizations (or network of organizations) to fulfill the customers' demand as a when they arise (Huber, 1984). Real option fulfills that necessity as well (Copeland and Tufano, 2004; Luherman, 1998).

Not recognizing the real option as strategic, decision making and valuation tool can lead to less than optimal choice in organization structure, decision making process and acquisition and utilization of technology. Such organizations can lock themselves in the wrong side of competition in the post-industrial environment (Huber, 1984; Venkatraman and Henderson, 1998).

\section{CONCLUSION}

Changing business environment requires change in the approach to managing "uncertainty." In industrial era "uncertainty" avoidance was the mantra. Now in the context of changing business environment, "uncertainty" should be taken as a reality and a challenge with potential for value addition. Organization should be flexible to be able to reap benefit from the environmental uncertainty. For flexibility in organization, resources should be deliberately developed and judiciously deployed (Huber, 1984).

The analytical tool of real option can be used by managers as guidance for decision making, resource development and management. It also gives the value for the management approach that the organization has taken to combat uncertainty (Leiblein, 2003). For these reason substantial portion of the value of modern post-industrial organization is represented by the real option (Venkatraman and Henderson, 1998).

By avoiding the real option as a valuation and decision making tool, organizations underestimate the projects with potential growth opportunities, and avoid developing resources that are necessary to be in business in the post industrial economy. Therefore, real option has become an essential tool for managers to understand and utilize.

\section{REFERENCES}

1. Adner, Ron and Levinthal, Daniel A., 2004, "What is not a Real Option: Considering Boundaries for the Application of Real Options to Business Strategy", Academy of Management Review, Vol. 29, No. 1, 74-85

2. Amram Martha and Kulatilaka Nalin, 1998, Real Options: Managing strategic Investments in an Uncertain World, Boston Massachusetts, Harvard Business School Press

3. Adner, Ron and Levinthal, Daniel A., 2004, "Real Options and Real Tradeoffs", Academy of Management Review, Vol. 29, No. 1, 120-126

4. Baldwin, C Y, Clark, K B, 1997, "Managing in an Age of Modularity", Harvard Business Review, 75 (5), 8494

5. Boyer, K.K., Leong,G.K., Ward, P.T. and Krajewski, L.J., 1997, "Unlocking the potential of advanced manufacturing technologies", Journal of Operations Management, 15, 331-347

6. Ching, Chee; Holsapple, Clyde W. and Whinston, Andrew B., 1996, "Toward IT support for coordination in network organizations", Information and Management 30, 179-199

7. Copeland, Tom and Tufano, Peter, 2004, “A Real World Way to Manage Real Options”, Harvard Business Review, March, 90-99

8. Copeland, Thomas E., Keenan, Philip T., 1998, "How much is Flexibility worth?”, The McKinsey Quarterly, Issue 2 
9. Copeland, Thomas E., Keenan, Philip T.,1998 “Making Real Options Real”, The McKinsey Quarterly, Issue 3

10. Doll W. J. and Vondermbse M., 1991 "The evolution of manufacturing system, towards post-industrial enterprise", Omega, Vol 19, No 5

11. Fine C., 1998, Clockspeed Winning Industry Control in Age of Temporary Advantage, Perseus Books

12. Fine, C and Raff D, 2000 "Internet-Driven Innovation and Economic Performance in the American Automobile Industry" web.mit.edu/afs/athena/org/c/ctpid/www/imvp/pub0001.htm

13. Frohlich, M., 1994, "How Do You Successfully Adopt an Advanced Manufacturing Technology?", European Management Journal, 16(2), pp 151-159

14. Galbraith, J.R., 1974, "Organizational Design, An Information Processing View”, Interfaces, 4(3), 28-36

15. Gerwin, D., 1993, "Manufacturing Flexibility, A Strategic Perspective", Management Science, 39(4), 395410

16. Huber, George P., 1984, "The Nature and Design of Post Industrial Organizations", Management Science, Vol. 30, No 8, August, 928-951

17. Hull, John C., 1997, Options, Futures and Other Derivatives, Third Edition, Upper Saddle River NJ, Prentice Hall

18. Jonquieres, Guy De, 1987, "Privatizing in a Bear Market”, Financial Times (London), Dec., Pg. 19

19. Kumar, R. L., 1995, "An option view of investment in expansion-flexible manufacturing systems", International Journal of Production Economics, 38, pp 281-291

20. Kumar, R.L., 1999, "Understanding DSS value: an option perspective", Omega Journal of International Management Science, 27, 295-304

21. Kulatilaka, N. and Venkatraman N., 2001, "Strategic Options in the Digital Era", Business Strategy Review, 12(4), 7-15

22. Kogut, Bruce and Kulatilaka, Nalin, 2004, "Real Options and Pricing and Organizations: The Contingent Risks of Extended Theoretical Domains", Vol. 29, No.1, 102-110

23. Koller, Timothy M., 2001, "Valuing dot-coms after the fall", The McKinsey Quarterly, Number 2

24. Leslie, Keith J and Michales, Max P., 1997, "The Real Power of Real Option”, Mckinsey Quarterly, Issue 3, 4-22

25. Leiblein, Michael J., 2003, "The Choice of Organizational Governance Form and Performance: Prediction From Transaction Cost, Resource-based, and Real Options Theories", Journal of Management, 29(6), 937961

26. Luherman, Timothy A., 1998, "Investment Opportunities as Real Options: Getting Started in Numbers", Harvard Business Review, July-Aug.,51-67

27. Magretta J, 1998 , "The Power of Virtual Integration: An Interview With Dell Computer's Michael Dell”, Harvard Business Review, March- April

28. McGrath Rita Gunther, Ferrier, Walter J and Mendelow, Aurbrey L., 2004, "Real Options As Engines of Choice and Heterogeneity", Academy of Management Review, Vol. 29, No. 1, 86 -101

29. Mendelson, H. and Pillai, R.R., 1999, "Industry Clockspeed: Measurement and Operational Implications", Manufacturing and Service Operations Management, 1(1), 1-20

30. Mendelson, H. and Pillai, R.R., 1998, "Clockspeed and Informational Response: Evidence from the Information Technology Industry", Information System Research, 9(4), 1998

31. Mukherjee A, and Laperè M and Wassenhove, 1990, "Knowledge Driven Quality Improvement", Management Science

32. Pandza, Krsto; Horsburth, Sturart; Gorton, Kevin and Polajnar, Andrey, 2003, "A real option approach to managing resources and capabilities", International Journal of Operations and Production Management, Vol 23, No 9, pp 1010-1032

33. Ramashesh, R.V. and Jayakumar M.D.,1993. "Economic Justification of Advanced Manufacturing Technology". Omega International Journal of Management Science, Vol.21, No.3, pp 289-306.

34. Riddell, Peter, 1987, "Troy Populism In Action”, Financial Times London, Oct 31, p. 7

35. Sako, M and Murray F. 1999, "Modular Strategies in Cars and Computers." web.mit.edu/afs/athena/ org/c/ctpid/www/imvp/pub99.htm

36. Sutcliffe, N. 1999, "Leadership behavior and business reengineering (BPR) outcome; An empirical analysis of 30 BPR projects". Information and Management 36 (5): 273-286 
37. Swamidass, P. Newell, W. T., 1987, "Manufacturing Strategy, environmental uncertainty and performance: a path analytical model". Management Science 33 (4), 509-524

38. Trigeogris, Lenos, 1993, "Real Options and Interaction with Financial Flexibility", Financial Management, Autumn; 202-224

39. Upton D. and McAfee A. 1996, “ The Real Virtual Factory”, Harvard Business Review, July - August

40. Venkatraman, N. 1998, "IT Agenda 2000: Not fixing Technical Bugs But Creating Business Value", European Management Journal, 16(5), 573-585

41. Venkatraman, N. and Henderson J.C, 1998, "Real Strategies for Virtual Organizations", Sloan Management Review, Fall, 33-48

42. Wilkinson, Max T, 1987, "BP tests the water", Financial Times (London), Dec 10, Pg 26

43. Zardkoohi, Asghar, 2004, "Do Real Options Lead to Escalation of Commitment", Academy of Management Review, Vol. 29, No. 1, 111-119

44. Zuboff S, 1982, "New worlds of computer-mediated work", Harvard Business Review, September-October

$\underline{\text { Notes }}$ 